This item was submitted to Loughborough's Research Repository by the author.

Items in Figshare are protected by copyright, with all rights reserved, unless otherwise indicated.

\title{
Taoism, Shintoism, and the ethics of technology: an ecocritical review of Howl's Moving Castle
}

PLEASE CITE THE PUBLISHED VERSION

http://dx.doi.org/10.5250/resilience.2.3.0189

\section{PUBLISHER}

(C) University of Nebraska Press

\section{VERSION}

NA (Not Applicable or Unknown)

\section{PUBLISHER STATEMENT}

This work is made available according to the conditions of the Creative Commons Attribution-NonCommercialNoDerivatives 4.0 International (CC BY-NC-ND 4.0) licence. Full details of this licence are available at: https://creativecommons.org/licenses/by-nc-nd/4.0/

\section{LICENCE}

CC BY-NC-ND 4.0

\section{REPOSITORY RECORD}

Wilson, Carl, and Garrath T. Wilson. 2019. "Taoism, Shintoism, and the Ethics of Technology: An Ecocritical Review of Howl's Moving Castle”. figshare. https://hdl.handle.net/2134/18428. 


\section{Ecocritical Review: Howl's Moving Castle (2004)}

\section{Carl Wilson \& Garrath Wilson}

Building on the continuing tropes that director Hayao Miyazaki and Studio Ghibli often reflect upon in the cores of their feature films, in Howl's Moving Castle, the themes of war, industrialisation, and metamorphosis compete, contrast, and comment upon notions of peace, nature and self-understanding.

In Howl's Moving Castle, Miyazaki is interested in exploring harmony through Taoism, especially through the notion of yin-yang, whereby oppositional forces are complementary, interrelated, and a part of nature. Howl is the central conduit through which many of these expressions can be found. The wizard Howl, dressed in white, is an adult with 'the heart of a child' who becomes increasingly infantile in his behaviour as a counterpoint to his fear that in joining an 'adult' conflict, he may lose his own humanity and permanently become a hideous, black crow-like creature of war, whose magical abilities will become co-opted into a great industrial war-machine that serves little purpose other than nihilistic destruction, eventually turning against nature itself. Man versus man; man versus nature (as magic); industry versus nature (as magic); and so on, are all encapsulated within Howl's conflicted being as he fights soldiers, wizards and flying machines. Yet, at no point does the film suggest that Howl should follow a redemption path to a hidden better-self which one might expect from a Western narrative of metamorphism such as Disney's Beauty and the Beast (1991). Instead, Howl's existence contains both yin and yang. Much like the pernicious threats facing No-Face In Spirited Away (2001) and Nago, the Boar God of Princess Mononoke (1997), Howl is a reflection of an environment that has been manipulated by mankind. With the help of young protege Markl, Howl already benevolently helps his various neighbours with his magic powers, so the use of spellcraft is never suggested to be inherently malevolent or corrupting. The implication is that the harmony within Howl's being depends upon an interconnected natural balance rather than denial, suppression and exclusion.

Sandwiched between Miyazaki's Spirited Away and Ponyo on the Cliff by the Sea (2008) - films which focus on the maturation of the child as they adjust to the 
Shinto/spiritual nature of the environment in which they live - Howl's Moving Castle also presents the viewer with Sophie Hatter. Sophie is an 18 year old girl who's coming-ofage story is ironically epitomised by a magical curse turning her into a 90 year old 'shriveled' lady. In contrast to Howl's development, Sophie constantly reiterates that she does not find herself 'pretty', but it is only once she, like Howl, is capable of attuning herself to her environment - not as an altruistic hat maker or cleaning lady who distances herself to a safe vantage point from which to help others - but as a selfconfident woman, that the spell is lifted.

Meanwhile, other characters in Howl's Moving Castle are pursuing their own aggressively self-serving agendas, whether it be the Witch of the Waste's 'greedy' capturing of Howl's heart, or Madam Suliman's manipulation of the war effort and disempowerment of rival wizards. Both of these characters have attained their place through an abuse of the equilibrium, but they know nothing about interpersonal relationships and are desperate to manipulate and control the environment in which they exist. The Witch is revealed to have put an anti-aging metamorphic spell upon herself, eventually becoming a lump of lipid goo - a transformative reflection of her true selfish state; and Suliman, who has legions of cloned servants comparative to the Witch's golem footmen, appears to reside within a self-contained greenhouse in contrast to the less controllable but more spectacular utopian environment that Howl helps to guide, shape, and share with Sophie, because 'he just wants to be free'.

The landscape of Diana Wynne Jones' source novel is partially based on Exmoor, and Essex (1), with one of the magical door's exits leading to Wales, yet for the adaptation, the design staff visited Europe, focusing on the eastern province of Alsace, France. (2) The verdant, blossoming, and distinctly European landscape also owes much to Miyazaki's earlier scene design work for Isao Takahata's 1974 anime series, Heidi, Girl of the Alps. In Howl's Moving Castle, the landscape dominates the frame of exterior shots. Houses, and by extension villages, towns and cities, all rest within fields of seemingly idyllic and infinite pastures (until mankind turns aspects of it into dark voids of scorched earth). When a massive zoomorphic object such as the castle lumbers and strains semi-syncopatically across the middle-distance, the mountains are always flanking it to a roughly equal height, whilst clouds envelop the puffing colossus, indeterminably mixing industrial steam and smoke with nature's counterpart. Fitting in 
with nature - not blended imperceptibly into the background, but as one component of many - the macroscale of the castle is analogous to the microscale industriousness of old Sophie, or the animals that the castle passes, such as the herds of sheep or wild antelope.

The castle epitomises Miyazaki's Taoist presentation of industrialism needing to be aligned with nature in order to negate any negative effects on humanity and the environment. Films such as Laputa: Castle in the Sky (1986) and Princess Mononoke show that it is possible to an extent for the two forces to peacefully co-exist, but the issue appears to be in communities overstepping the boundaries that nature has provided for them.

Howl's Moving Castle is 'set in a world conceived by the late 19th century European neo-futurist painters where magic and science co-exist' (3). Within this Victoriana steampunk world, where coal powered trains are juxtaposed with electrically powered air battalion bombers, Howl takes refuge in his moving castle, where 'Powered by the fire demon Calcifer, the noisy castle emits steam and roams around like a living creature [...] covered with houses, cannons, and other disparate parts including ears and assorted junk.'(4) The animistic castle, and the other semi-organic creations within the story are reminiscent of Frankenstein's patchwork creation, who only became a 'monster' once he interacted with human beings. Technology, like the wizards fighting the war, 'pollution', or even becoming old, is neither inherently good nor bad; it depends upon its context, use, and designation. Driven by a demon fire spirit which is tempered by the presence of Howl's heart, the castle represents a temporary harmony between the ethics of technology and the intent of the user.

Howl detests combat and the idea of taking sides in such a pointless conflict. When Sophie spies an airship in the distance, she asks Howl: 'Is it the enemy's or one of ours?', to which she gets the stark response: 'What difference does it make? Those stupid murderers.' If Howl was in danger of letting his own place run into disrepair or disgrace, Sophie appears at exactly the right moment to literally and metaphorically brighten the place up and restore balance. When the battleship flotilla appears it seems to be gleaming with modernity and parading righteousness, but once Howl encounters the various enemies in actual combat, and a bomber partially destroys Sophie's hometown, the magic/hate-fuelled war machines appear to become more feral in their 
appearance and actions, as misappropriation of nature (channeled through magic) does not reduce its presence, but distorts it.

Howl may have stolen or created his cannon-covered castle when terminating his apprenticeship with Suliman, so the castle does mirror some of the more bloodthirsty enemies or personal impulses that Howl encounters. Yet, given the symbolism of his heart being in the centre of it, which significantly differentiates his mobile home from the militaristic others, as a representation of domesticity and perpetual internalised tensions the home is equally analogous to Sophie's mother who early on in the story wears a striking hat that is adorned with both flowers and cannons. Honey Hatter's garments do not make her inherently flawed; but as with the castle, they do provide narrative space to allow for the possibility of manipulation later on in the story, just as Suliman tries to exert a hold over Howl, and very nearly succedes.

Along with Taoism, Shintoism is a key concept to understanding the way that the environment works in Howl's Moving Castle. Shinto shrines - fixed focal points where 'kami', or spirits, converge and share their interrelated energies with receptive visitors can be found in Ghibli films such as Spirited Away, My Neighbour Totoro (1988), and Pom Poko (1994). Howl's castle could also be thought of as a type of Shinto shrine, enabling Howl's heart to be kept safe, whilst also representing symbolic and real barriers between spaces in the form of the magical portal door. Furthermore, when Howl is attempting to reignite Calcifer into rebuilding the castle, he makes a tokenistic shrine offering of Sophie's braid as a social and spiritual contract tying them all together.

In Shintoism impure pollutants are called 'kegare'. Bathing in Shintoism is also a frequently practised cleansing purification ritual, which Howl repeats until his potions are 'completely ruined' by Sophie. It is at this point that the viewer sees kegare in the form of green ooze when Howl is narcissistically despairing about his appearance. More significantly, kegare is present in the globular footmen of the Witch of the Waste. Diana Wynne Jones, the novelist who wrote the original source material, believes that Miyazaki had directly imported and overlayed his own feelings about World War II into the animated adaptation,(5) but Miyazaki has also stated that the film is 'profoundly affected by the war in Iraq'.(6) It therefore makes sense that in comparison to the purer energy of Calcifer, who operates the castle, the Witch's servants appear to be made of oil as they are literally the impure fuel that drives her sedan chair and powers several of 
the warring airships. By extension, when Sophie wonders why nobody can see the blob men as the battleships are leaving the harbor for war, it is arguably because they represent the covert interests of Big Companies that are happy to exploit people's inane justifications for self-perpetuating war, whilst being complicit in profitable attempts to find further sources of oil/kegare. In Howl's Moving Castle it is significant that the motivations for war are only minimally implied, and nobody can think about them or the Big Companies because their attention is diverted. Consequently, the Witch of the Waste is more than happy to visit the King and receive sanctioned blessing for her seemingly magical 'Waste' corporation; what she didn't anticipate was the intervention of the government and their attempt to seize control of all (magic) business interests and assets into their own portfolio.

It is only once Suliman can see that Prince Justin has been returned to his normal form and that Howl has 'found his true love' that she can declare: 'The game is over. Get me the Prime Minister and the Minister of Defense. Let's put an end to this idiotic war.' However, a number of things are not clear in this resolution, such as what happened to Justin to metamorphosize him into Turnip Head in the first place, and why? Perhaps of more importance for narrative closure is whether Suliman's ambiguous 'game' was the physical industry of battle that caused an untold number of deaths and damage to the environment, or an infatuation with corrupting/owning Howl. Both solutions are not mutually exclusive, and it is quite significant that whilst Sophie et al, are awarded the 'Happy Ending', there still looms over them and the whole region, the threat that the whole scenario could easily be repeated at a later date. In a Disney film, this would be incongruous; but in a Ghibli film, this is the epitome of yin-yang. 


\section{Notes:}

1. Wynne Jones, Howl's Moving Castle, 316.

2. Ghibli and Oniki, The Art of Howl's Moving Castle, 12.

3. Ghibli and Oniki, The Art of Howl's Moving Castle, 10.

4. Ghibli and Oniki, The Art of Howl's Moving Castle, 37.

5. Wynne Jones, Howl's Moving Castle, 316.

6. Odell and Le Blanc, Studio Ghibli: The Films of Hayao Miyazaki and Isao Takahata, 127.

\section{Works Cited:}

Odell, Colin, and Michelle Le Blanc. Studio Ghibli: The Films of Hayao Miyazaki and Isao Takahata. Harpenden: Kamera Books, 2009.

Studio Ghibli and Yuji Oniki (English Adaptation). The Art of Howl's Moving Castle. San Francisco: VIZ Media, LLC, 2005.

Wynne Jones, Diana. Howl's Moving Castle. London: Harper Collins Children's Books, 2009. 